\title{
Kushneria sinocarnis sp. nov., a moderately halophilic bacterium isolated from a Chinese traditional cured meat
}

\author{
Zhengzhong Zou and Gejiao Wang
}

Correspondence

Gejiao Wang

gejiaow@yahoo.com.cn or

gejiao@mail.hzau.edu.cn State Key Laboratory of Agricultural Microbiology, College of Life Science and Technology,
Huazhong Agricultural University, Wuhan 430070, PR China
The family Halomonadaceae, within the class Gammaproteobacteria, was proposed by Franzmann et al. (1988). Because of the diversity of the family Halomonadaceae and the lack of typical differential phenotypic traits, many Gram-negative halophilic microorganisms that were previously classified as members of genera Deleya, Arthrobacter, Flavobacterium, Volcaniella, Halovibrio, Paracoccus, Alcaligenes and Pseudomonas are now assigned to the family Halomonadaceae (Ventosa et al., 1998). Based on $16 \mathrm{~S}$ and $23 \mathrm{~S}$ rRNA gene sequence relationships and phenotypic features, this heterogeneous group was re-evaluated (Arahal et al., 2002; Dobson et al., 1993; Mata et al., 2002). At the time of writing, there were nine genera in the family Halomonadaceae: Chromohalobacter, Carnimonas, Cobetia, Halomonas, Halotalea, Modicisalibacter, Salinicola, Zymobacter and Kushneria. Halomonas was the largest genus in this family and contained 56 species with validly published names. Chromohalobacter contained nine species. The six genera, Carnimonas, Cobetia, Halotalea, Modicisalibacter, Salinicola and Zymobacter, each contained only one species (Arahal \& Ventosa, 2008).

The GenBank/EMBL/DDBJ accession numbers for the $16 \mathrm{~S}$ and $23 \mathrm{~S}$ rRNA gene sequences of strain $Z_{35}^{\top}$ are FJ667549 and FJ797433, respectively.

A supplementary figure showing a scanning electron micrograph of cells of strain $\mathrm{Z}^{\mathrm{T}}{ }^{\mathrm{T}}$ is available with the online version of this paper.
Recently, Sánchez-Porro et al. (2009) described a new genus, Kushneria, with the type species Kushneria aurantia, and reclassified Halomonas marisflavi (Yoon et al., 2001), Halomonas indalinina (Cabrera et al., 2007) and Halomonas avicenniae (Soto-Ramirez et al., 2007) as Kushneria marisflavi, Kushneria indalinina and Kushneria avicenniae, respectively. The distinct characteristics of the genus were being oxidase-negative and having small amounts of Q-8 and Q-10 in the respiratory quinone system relative to the most closely related genus, Halomonas.

The majority of members of the family Halomonadaceae have been isolated from marine and saline environments (Ventosa et al., 1998) and rarely from cured-meat products. To our knowledge, there are only three species within the family Halomonadaceae isolated from this type of environment: Carnimonas nigrificans (Garriga et al., 1998) from raw cured-meat products; Halomonas halodenitrificans (Dobson \& Franzmann, 1996) from meatcuring brines; and Halomonas alimentaria (Yoon et al., 2002) from a traditional Korean fermented seafood. This study describes a Gram-negative, moderately halophilic bacterium, strain $\mathrm{Z}^{3} 5^{\mathrm{T}}$, isolated from a piece of Chinese traditional salty pork that was cured with salt in Wuhan, and concludes that strain $235^{\mathrm{T}}$ represents a novel member of the genus Kushneria.

For the isolation of strain $\mathrm{Z}^{3} 5^{\mathrm{T}}$, the cured meat was cut into small pieces, added to sterile HGM liquid medium [containing (all $\mathrm{l}^{-1}$ ): $19.5 \mathrm{~g} \quad \mathrm{MgCl}_{2} .6 \mathrm{H}_{2} \mathrm{O}, 29.0 \mathrm{~g}$ 
$\mathrm{MgSO}_{4} .7 \mathrm{H}_{2} \mathrm{O}, 1.1 \mathrm{~g} \mathrm{CaCl}_{2} .2 \mathrm{H}_{2} \mathrm{O}, 6.0 \mathrm{~g} \mathrm{KCl}, 0.5 \mathrm{~g} \mathrm{NaBr}$, $10.0 \mathrm{~g}\left(\mathrm{NH}_{4}\right)_{2} \mathrm{SO}_{4}, 174.0 \mathrm{~g} \mathrm{NaCl}, 3.0 \mathrm{~g}$ yeast extract, with $10 \mathrm{mM}$ Tris- $\mathrm{HCl}$ buffer to maintain the $\mathrm{pH}$ at 7.0; Fairley et al., 2002] and incubated at $37{ }^{\circ} \mathrm{C}$ for $24 \mathrm{~h}$ with rotation at 200 r.p.m. After this enrichment cultivation, an aliquot of the solution was diluted with $10 \% \mathrm{NaCl}$ solution and streaked onto HGM agar plates and incubated at $37^{\circ} \mathrm{C}$ for 2 weeks. Single colonies were subcultivated several times to obtain a pure culture.

For taxonomic characterization, strain $\mathrm{Z}^{3} 5^{\mathrm{T}}$ was grown in MH medium (Ventosa et al., 1982) at $37{ }^{\circ} \mathrm{C}$ unless otherwise stated. Cell morphology was observed using a scanning electron microscope (JSM-6390/LV; JEOL) with $20 \mathrm{kV}$ accelerating voltage and at magnification $\times 10000$. Before observation, bacterial colonies from the plates were bound to slides and fixed with $2.5 \%(\mathrm{v} / \mathrm{v})$ glutaraldehyde solution. After washing, cells were dehydrated with ethanol and coated with gold.

The optimal conditions for growth were determined in $\mathrm{MH}$ medium containing $0,0.5,1,3,5,7.5,10,12.5,15,20,25$ and $30 \%(\mathrm{w} / \mathrm{v})$ total salts, as well as in MH medium in which only the $\mathrm{NaCl}$ concentration was changed. The specific ionic requirement was examined in $\mathrm{MH}$ medium without $\mathrm{Mg}^{2+}$, $\mathrm{Ca}^{2+}$ and/or $\mathrm{K}^{+}$. Growth was also tested with $\mathrm{NaCl}$ substituted by $\mathrm{KCl}$. The $\mathrm{pH}$ range for growth was determined in filter-sterilized MH medium buffered with hydrogen acetate/sodium acetate ( $\mathrm{pH} 4.0-4.5), 10 \mathrm{mM}$ MES (pH 5.0-6.0), $10 \mathrm{mM}$ PIPES ( $\mathrm{pH} 6.5-7.0$ ), $10 \mathrm{mM}$ Tris/HCl (7.5-9.0) and adjusted with $\mathrm{NaOH}$ or $\mathrm{HCl}$. The $\mathrm{pH}$ range for growth was tested at $\mathrm{pH} 4.0-10.0$ in increments of $\mathrm{pH}$ 0.5. Growth was determined at $A_{600}$. Growth at $0,4,15$, $20,28,37,42$ and $45^{\circ} \mathrm{C}$ was also determined.

Phenotypic characterizations were performed following the recommended minimal standards for describing new taxa of the family Halomonadaceae (Arahal et al., 2007). Gramstaining reaction was determined using the method described by Dussault (1955). Growth under anaerobic conditions was studied in semi-solid MH medium $(0.6 \%$, $\mathrm{w} / \mathrm{v}$, agar) by inoculation at the bottom of the tube, sealing with $2 \mathrm{ml}$ agar $(2 \%, \mathrm{w} / \mathrm{v})$ and $2 \mathrm{ml}$ paraffin. Acid production from carbohydrates was determined using bromocresol purple supplemented with $1 \%$ of the carbohydrate and liquid MH medium. Nutritional tests were analysed according to Arahal et al. (2007). Substrates were added as filter-sterilized solutions to basal medium [(all $\left.\mathrm{l}^{-1}\right): 75 \mathrm{~g} \mathrm{NaCl}, 2 \mathrm{~g} \mathrm{KCl}, 0.2 \mathrm{~g} \mathrm{MgSO}_{4} .7 \mathrm{H}_{2} \mathrm{O}, 1 \mathrm{~g} \mathrm{KNO}_{3}$, $\left.1 \mathrm{~g}\left(\mathrm{NH}_{4}\right)_{2} \mathrm{HPO}_{4}, 0.5 \mathrm{~g} \mathrm{KH}_{2} \mathrm{PO}_{4}\right]$ to give a final concentration of $1 \mathrm{~g} \mathrm{l}^{-1}$, except for carbohydrates which were used at $2 \mathrm{~g} \mathrm{l}^{-1}$. When the substrate was an amino acid, it was tested as a carbon, nitrogen and energy source and therefore the basal medium was prepared without $\mathrm{KNO}_{3}$ and $\left(\mathrm{NH}_{4}\right)_{2} \mathrm{HPO}_{4}$. Other morphological, physiological and biochemical characteristics were determined as described by Mata et al. (2002). Oxidase reaction and additional biochemical tests were performed using the API $20 \mathrm{NE}$ system (bioMérieux), according to the manufacturer's instructions, except that the culture was suspended in artificial seawater solution (w/v: $10 \% \mathrm{NaCl}, 0.594 \%$ $\mathrm{MgSO}_{4} \cdot 7 \mathrm{H}_{2} \mathrm{O}, \quad 0.453 \% \quad \mathrm{MgCl}_{2} \cdot 6 \mathrm{H}_{2} \mathrm{O}, 0.064 \% \mathrm{KCl}$, $0.013 \% \mathrm{CaCl}_{2}$ ). All phenotypic characterizations were done using $K$. avicenniae $\mathrm{MW}^{\mathrm{T}} \mathrm{a}^{\mathrm{T}}$ as a reference (SotoRamirez et al., 2007).

The nearly full-length $16 \mathrm{~S}$ rRNA gene sequence was amplified by PCR with universal primers Uni-27F and Uni-1492R (Wilson et al., 1990) and the PCR products were ligated into the pGEM-T vector (Promega). The fulllength $23 \mathrm{~S}$ rRNA gene sequence was obtained by PCR with two sets of primer pairs: 1310V (5'-GAGTCTGCAACTCGACT-3', forward, positions 1310-1326, Escherichia coli 16S rRNA gene sequence numbering; this work) and 985R (5'-CCGGTCCTCTCGTACT-3', reverse; Arahal et al., 2002; E. coli positions 2654-2669); and 1023V (5'GCGTAAYAGCTCACT-3', forward; E. coli positions 1091-1105) and 504R (5'-SWGTTCGRVAWGGGA-3', reverse; E. coli positions 33-49) (Arahal et al., 2002). DNA sequencing was performed at the Beijing Genomics Institute (Beijing, PR China). The sequences were initially compared with the sequences in the GenBank database. Subsequently, the $16 \mathrm{~S}$ and $23 \mathrm{~S}$ rRNA gene sequences were aligned with those of closely related strains of the family Halomonadaceae using the CLUSTAL $\mathrm{w}$ algorithm with default parameters (Thompson et al., 1994). Phylogenetic analysis was carried out using MEGA 4.0 (Tamura et al., 2007). Distances and clustering were determined using the neighbour-joining and maximum-parsimony methods with bootstrap analyses based on 1000 replications.

The genomic DNA G $+C$ determination and chemotaxonomic study of strain $\mathrm{Z}^{3} 5^{\mathrm{T}}$, including whole-cell fatty acid and isoprenoid quinone analyses, were carried out by the China Center for Type Culture Collection (Wuhan, PR China). $\mathrm{G}+\mathrm{C}$ content was determined by HPLC according to the method of Mesbah et al. (1989). Respiratory lipoquinone analysis was performed by HPLC as described by Xie \& Yokota (2003). For whole-cell fatty acid analysis, strain $\mathrm{Z}_{3} 5^{\mathrm{T}}$ and the type strains of the genus Kushneria were grown on SW10 agar at $37{ }^{\circ} \mathrm{C}$ for $48 \mathrm{~h}$ supplemented with $10 \% \mathrm{NaCl}$ and analysed by GC (Hewlett Packard 6890) according to the Sherlock Microbial Identification System (MIDI) instructions. Fatty acids in strain $\mathrm{Z}^{3} 5^{\mathrm{T}}$ after growth on TSB agar were also analysed.

The cell size and morphology of strain $\mathrm{Z}^{2} 5^{\mathrm{T}}$ is shown in Supplementary Fig. S1 (available in IJSEM Online). Detailed results of the morphological, physiological and biochemical characteristics of strain $\mathrm{Z}^{\mathrm{T}} 5^{\mathrm{T}}$ are given in the species description. Strain $\mathrm{Z} 35^{\mathrm{T}}$ shared some characteristics with the type strains of the other Kushneria species but also many differences: the main phenotypic differences are shown in Table 1.

The 16S rRNA gene sequence analysis indicated that strain $\mathrm{Z}^{3} 5^{\mathrm{T}}$ was closely related to K. aurantia $\mathrm{A} 10^{\mathrm{T}}$ (95.3\% $16 \mathrm{~S}$ rRNA gene sequence similarity), $K$. avicenniae $\mathrm{MW}^{2} \mathrm{a}^{\mathrm{T}}$ $(94.1 \%), K$. marisflavi SW $32^{\mathrm{T}}(93.7 \%)$ and $K$. indalinina 
Table 1. Differential characteristics of strain $Z 35^{\top}$ and the type strains of the genus Kushneria

Strains: 1, Kushneria sinocarnis sp. nov. $\mathrm{Z}^{\mathrm{T}}{ }^{\mathrm{T}}$ (data from this study); 2, K. avicenniae MW2a ${ }^{\mathrm{T}}$ (Soto-Ramirez et al., 2007); 3, K. marisflavi SW32 ${ }^{\mathrm{T}}$ (Yoon et al., 2001; Mata et al., 2002); 4, K. indalinina CG2.1 ${ }^{\mathrm{T}}$ (Cabrera et al., 2007); 5, K. aurantia A10 ${ }^{\mathrm{T}}$ (Sánchez-Porro et al., 2009). +, Positive; + -, weakly positive; - , negative.

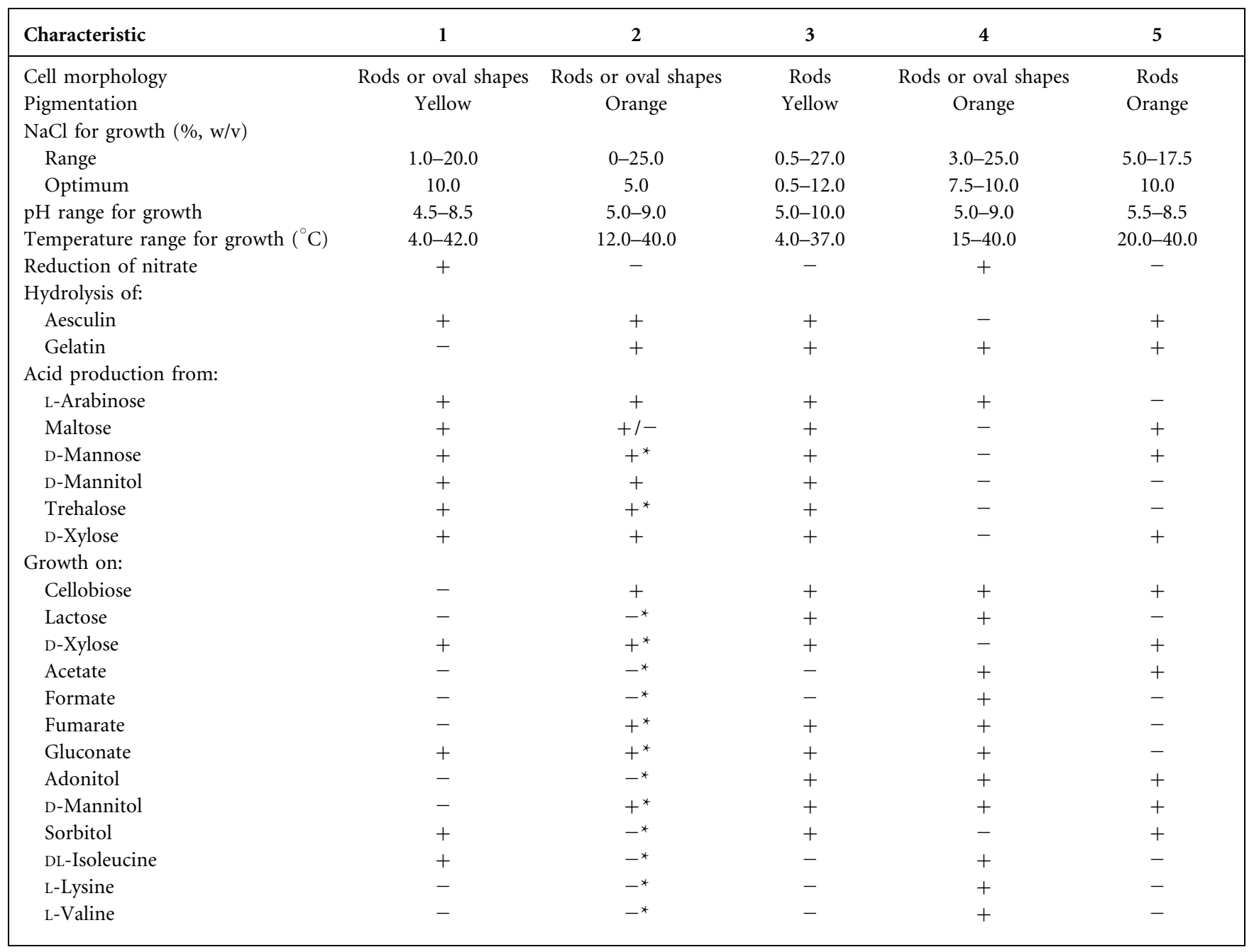

${ }^{\star}$ Data determined in this study.

CG2.1 ${ }^{\mathrm{T}}(93.7 \%)$. The phylogenetic tree constructed using the neighbour-joining algorithm revealed that strain $\mathrm{Z}_{3} 5^{\mathrm{T}}$ belongs to the cluster of strains of the genus Kushneria with high bootstrap support (Fig. 1a). The maximum-parsimony algorithm gave a similar result (data not shown). The 16S rRNA gene sequence of strain $\mathrm{Z}^{3} 5^{\mathrm{T}}$ contained the 15 signature nucleotides defined for members of the family Halomonadaceae (Ben Ali Gam et al., 2007).

A complete $23 \mathrm{~S}$ rRNA gene sequence (2919 bp) of strain $\mathrm{Z} 35^{\mathrm{T}}$ was obtained and compared with those of type strains of the family Halomonadaceae. The 23S rRNA gene sequence similarities of strain $\mathrm{Z}^{\mathrm{T}} 5^{\mathrm{T}}$ with its closest neighbours were as follows: K. aurantia $\mathrm{A}_{10}{ }^{\mathrm{T}}, 93.4 \%$; $K$. avicenniae $\mathrm{MW} 2 \mathrm{a}^{\mathrm{T}}, 92.5 \%$; K. marisflavi DSM $15357^{\mathrm{T}}$, $92.1 \%$; and $K$. indalinina CG2.1 ${ }^{\mathrm{T}}, 92.1 \%$. These results were very similar to those with the $16 \mathrm{~S}$ rRNA gene, which confirmed the phylogenetic affinity of strain $\mathrm{Z} 35^{\mathrm{T}}$ to the genus Kushneria (Fig. 1b). The maximum-parsimony algorithm gave a similar result (data not shown).

The G+C content of the strain $\mathrm{Z}^{2} 5^{\mathrm{T}}$ was $59.1 \mathrm{~mol} \%$, which was very similar to those of the other species of the genus Kushneria. The isoprenoid quinones of strain $\mathrm{Z}^{3} 5^{\mathrm{T}}$ consisted of Q-9 (88.96\%), Q-8 (9.46\%) and a small amount of Q-10 (1.58\%). The major cellular fatty acids of strain $\mathrm{Z}_{3} 5^{\mathrm{T}}$ were $\mathrm{C}_{19: 0}$ cyclo $\omega 8 c, \mathrm{C}_{16: 0}$ and $\mathrm{C}_{17: 0}$ cyclo (Table 2). Comparing the amounts found in strain $\mathrm{Z}_{3} 5^{\mathrm{T}}$ with those found in the type strains of the genus Kushneria (Table 2) showed that strain $\mathrm{Z}_{3} 5^{\mathrm{T}}$ contained lower levels of $\mathrm{C}_{18: 1} \omega 7 c$ and $\mathrm{C}_{12: 0} 3-\mathrm{OH}$ and higher levels of $\mathrm{C}_{12: 0}, \mathrm{C}_{17: 0}$ cyclo and $\mathrm{C}_{19: 0}$ cyclo $\omega 8 c$. In addition, strain $\mathrm{Z}_{3} 5^{\mathrm{T}}$ contained small amounts of $\mathrm{C}_{18: 1} \omega 9 c$ and iso- $\mathrm{C}_{13: 0} 3$ $\mathrm{OH}$ that were not found in the other type strains. TSB 


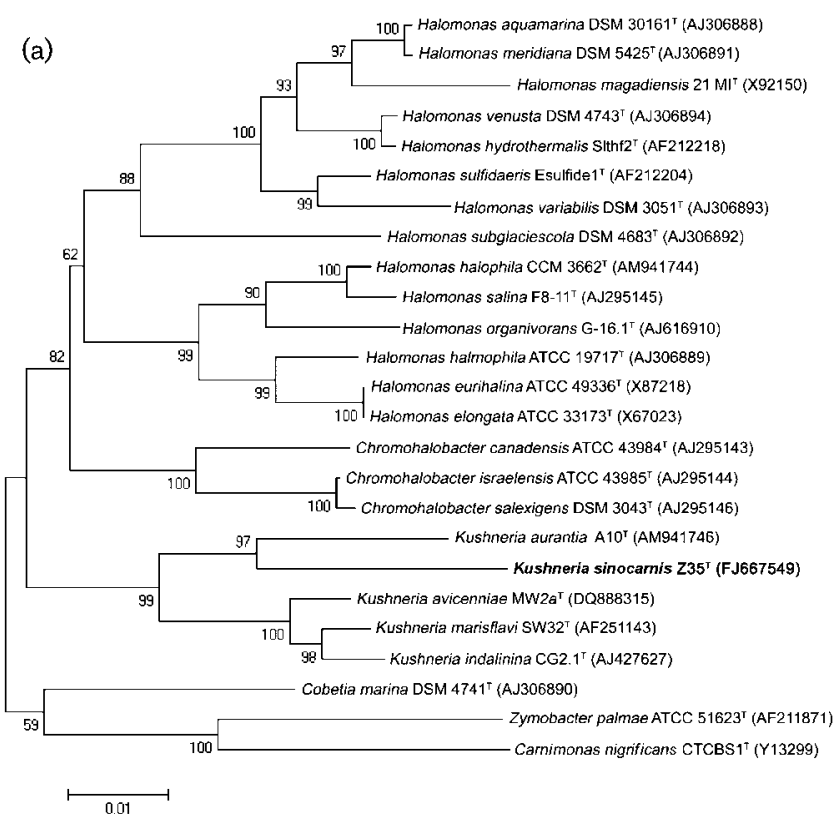

Table 2. Whole-cell fatty acids of strain $Z 35^{\top}$ and the type strains of the genus Kushneria

Strains: 1, Kushneria sinocarnis sp. nov. $\mathrm{Z}^{\mathrm{T}}{ }^{\mathrm{T}} ; 2, \mathrm{~K}$. avicenniae MW2 $\mathrm{a}^{\mathrm{T}}$; 3, K. marisflavi DSM $15357^{\mathrm{T}}$; 4, K. indalinina CG2.1 ${ }^{\mathrm{T}} ; 5, \mathrm{~K}$. aurantia $\mathrm{A} 10^{\mathrm{T}}$. Data for strains $2-5$ were taken from Sánchez-Porro et al. (2009). All strains were cultured on SW10 medium at pH 7.0 and $37{ }^{\circ} \mathrm{C}$ for $24 \mathrm{~h}$.

\begin{tabular}{|lccccc|}
\hline Fatty acid & $\mathbf{1}$ & $\mathbf{2}$ & $\mathbf{3}$ & $\mathbf{4}$ & $\mathbf{5}$ \\
\hline $\mathrm{C}_{10: 0}$ & 0.2 & 1.0 & 2.4 & 1.6 & 1.1 \\
$\mathrm{C}_{12: 0}$ & 3.3 & 0.8 & - & 0.8 & 0.8 \\
$\mathrm{C}_{12: 0} 2-\mathrm{OH}$ & 1.0 & 3.2 & 3.2 & 3.6 & 0.4 \\
$\mathrm{C}_{12: 0} 3-\mathrm{OH}$ & 4.5 & 11.3 & 11.0 & 12.1 & 8.8 \\
iso- $_{13: 0} 3-\mathrm{OH}$ & 0.7 & - & - & - & - \\
$\mathrm{C}_{14: 0}$ & 1.7 & 0.4 & 0.5 & 0.7 & 1.9 \\
$\mathrm{Summed} \mathrm{feature}^{*}$ & 2.3 & 2.6 & 3.5 & 4.2 & 3.5 \\
$\mathrm{C}_{16: 0}$ & 27.3 & 37.4 & 33.4 & 40.7 & 40.4 \\
$\mathrm{C}_{17: 0}$ cyclo & 11.2 & 3.2 & 2.6 & 2.2 & 0.9 \\
$\mathrm{C}_{18: 1} \omega 7 c$ & 6.4 & 16.6 & 25.7 & 20.0 & 28.4 \\
$\mathrm{C}_{18: 1} \omega 9 c$ & 1.4 & - & - & - & - \\
$\mathrm{C}_{18: 0}$ & 3.7 & 1.2 & 2.1 & 1.0 & 1.1 \\
$\mathrm{C}_{19: 0}$ cyclo $\omega 8 c$ & 33.9 & 22.3 & 15.7 & 12.9 & 11.8 \\
\hline
\end{tabular}

(b)

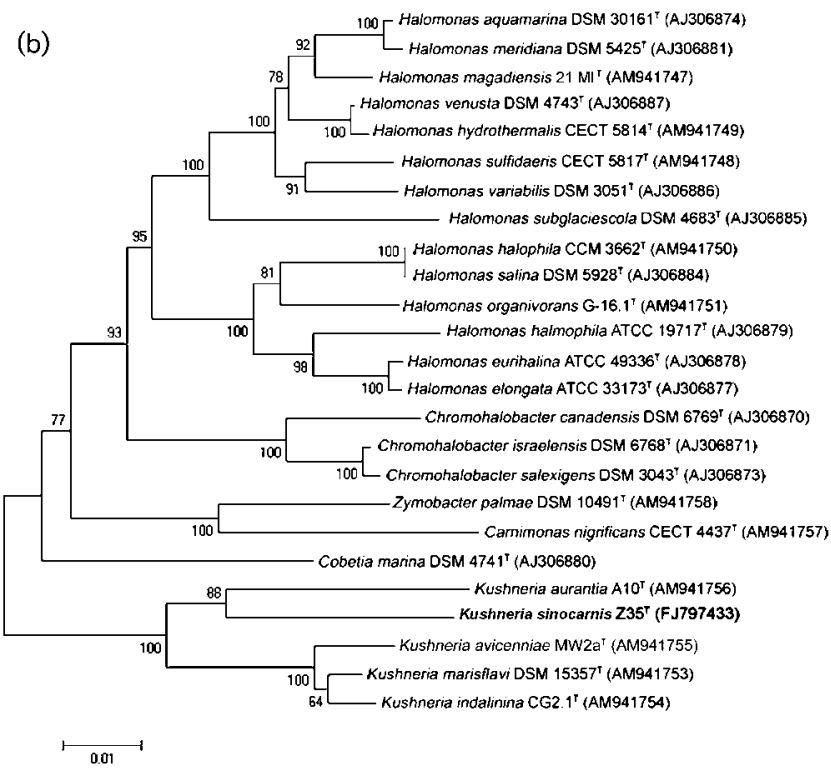

Fig. 1. Neighbour-joining trees based on (a) $16 \mathrm{~S}$ and (b) $23 \mathrm{~S}$ rRNA gene sequences showing the phylogenetic positions of

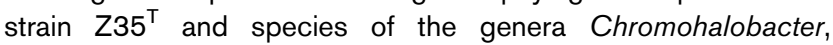
Carnimonas, Cobetia, Halomonas, Zymobacter and Kushneria. Percentages at nodes are bootstrap values based on 1000 replications. Bars, 0.01 substitutions per nucleotide position.

medium was also used for the fatty acid analysis of strain $\mathrm{Z35}^{\mathrm{T}}$ and very similar results were obtained (data not shown).

On the basis of phylogeny, whole-cell fatty acid and quinone compositions and phenotypic traits, we conclude that strain $235^{\mathrm{T}}$ represents a novel species of the genus Kushneria, for which we propose the name Kushneria sinocarnis sp. nov.
*Summed features represent two or three fatty acids that cannot be separated by the Microbial Identification System. Summed feature 3 consisted of $\mathrm{C}_{16: 1} \omega 7 c$ and/or iso- $\mathrm{C}_{15: 0} 2-\mathrm{OH}$

\section{Description of Kushneria sinocarnis sp. nov.}

Kushneria sinocarnis (si.no.car'nis. M.L. n. Sina China; L. n. caro, carnis flesh, meat; N.L. gen. n. sinocarnis of a Chinese meat, relating to the Chinese traditional cured meat from which the organism was first isolated).

Cells are Gram-negative, non-motile rods or oval shapes $(0.5-0.8 \times 1.4-3.5 \mu \mathrm{m})$. Colonies on $\mathrm{MH}$ medium are yellow, circular, smooth and convex after incubation for 2 days. Aerobic, moderately halophilic. Growth occurs at $1-20 \%(\mathrm{w} / \mathrm{v}) \mathrm{NaCl}$ (optimum $10 \%$ ) and 5-30\% (w/v) total salts (optimum 12.5\%). No growth in the absence of $\mathrm{NaCl}$ : $\mathrm{KCl}$ cannot substitute $\mathrm{NaCl}$. Growth occurs at $4-$ $42{ }^{\circ} \mathrm{C}$ (optimum $37{ }^{\circ} \mathrm{C}$ ), but not at 0 or $45^{\circ} \mathrm{C}$, and $\mathrm{pH}$ 4.5-8.5 (optimum $\mathrm{pH} 7.0$ ). Respiration with fumarate and nitrate is positive but with nitrite is negative. No production of exopolysaccharide or poly- $\beta$-hydroxybutyrate. Grows on MacConkey agar supplemented with $10 \%$ (w/v) artificial seawater. Oxidase-negative, catalase-positive and negative for fermentation of D-glucose. Nitrate is reduced to nitrite but not to nitrogen. Indole and $\mathrm{H}_{2} \mathrm{~S}$ are not produced. Methyl red and Voges-Proskauer tests are negative. ONPG and PNPG test results are positive. Aesculin and Tween 20 are hydrolysed, but starch, casein, gelatin, tyrosine, urea, DNA and Tween 80 are not hydrolysed. Lysine decarboxylase, ornithine decarboxylase, phenylalanine deaminase and arginine dihydrolase are not produced. Acid is produced from adonitol, L-arabinose, Dfructose, D-galactose, D-glucose, lactose, maltose, D-man- 
nitol, D-mannose, L-rhamnose, D-salicin, D-sorbitol, sorbose, trehalose and D-xylose, but not from myo-inositol, melezitose, raffinose, ribose or sucrose. The following substrates are utilized as sole carbon and nitrogen sources: L-arabinose, D-fructose, D-galactose, D-glucose, maltose, Dmannose, melibiose, ribose, sucrose, trehalose, D-xylose, citrate, lactate, pyruvate, gluconate, succinate, glycerol, sorbitol, L-glutamate, L-proline, DL-isoleucine and L-serine. The following substrates are not utilized: aesculin, cellobiose, lactose, melezitose, raffinose, L-rhamnose, Dsalicin, starch, acetate, formate, fumarate, malonate, propionate, caprylate, benzoate, hippurate, malate, tartrate, adonitol, ethanol, 1,2-propanediol, myo-inositol, D-mannitol, methanol, $N$-acetylglucosamine, DL- $\beta$-hydroxybutyrate, L-alanine, L-histidine, L-lysine, L-methionine, L-valine, L-arginine, L-aspartate, creatine, L-cysteine, L-leucine, Lornithine, L-phenylalanine, L-threonine and L-tryptophan. Resistant to ( $\mu \mathrm{g} \mathrm{ml}^{-1}$ unless otherwise stated) amoxicillin (20), ampicillin (10 U), cefotaxime (30), clavulanic acid (10), cefoxitin (30), chloramphenicol (30), kanamycin (30), nalidixic acid (30), polymyxin B (25), streptomycin (10), tobramycin (10) and trimethroprim/sulphamethoxazol (5). Sensitive to erythromycin (15) and nitrofurantoin (300). The quinone system consists of Q-9 and small amounts of Q-8 and Q-10. The major fatty acids (>5\%) are $\mathrm{C}_{19: 0}$ cyclo $\omega 8 c, \mathrm{C}_{16: 0}, \mathrm{C}_{17: 0}$ cyclo, $\mathrm{C}_{18: 1} \omega 7 c$ and $\mathrm{C}_{12: 0}$ 3-OH. The DNA G+C content of the type strain is $59.1 \mathrm{~mol} \%$ (HPLC).

The type strain, $\mathrm{Z35}^{\mathrm{T}}\left(=\mathrm{CCTCC} \mathrm{AB} 209027^{\mathrm{T}}=\mathrm{NRRL}\right.$ $\mathrm{B}-59197^{\mathrm{T}}=\mathrm{DSM} 23229^{\mathrm{T}}$ ), was isolated from Chinese traditional cured meat in Wuhan, Hubei Province, PR China.

\section{Acknowledgements}

We would like to thank Dr Rafael Montalvo-Rodríguez (University of Puerto Rico) for kindly providing K. avicenniae MW2 $\mathrm{a}^{\mathrm{T}}$. This work was supported by the National Science Foundation of China (30671140) and the Returning Overseas Scientist Fund of the Ministry of Education of China for G. W.

\section{References}

Arahal, D. R. \& Ventosa, A. (2008). International Committee on Systematics of Prokaryotes: subcommittee on the taxonomy of Halomonadaceae. Int J Syst Evol Microbiol 58, 2670-2671.

Arahal, D. R., Ludwig, W., Schleifer, K. H. \& Ventosa, A. (2002). Phylogeny of the family Halomonadaceae based on 23S and 16S rDNA sequence analyses. Int J Syst Evol Microbiol 52, 241-249.

Arahal, D. R., Vreeland, R. H., Litchfield, C. D., Mormile, M. R., Tindall, B. J., Oren, A., Bejar, V., Quesada, E. \& Ventosa, A. (2007). Recommended minimal standards for describing new taxa of the family Halomonadaceae. Int J Syst Evol Microbiol 57, 2436-2446.

Ben Ali Gam, Z., Abdelkafi, S., Casalot, L., Tholozan, J. L., Oueslati, R. \& Labat, M. (2007). Modicisalibacter tunisiensis gen. nov., sp. nov., an aerobic, moderately halophilic bacterium isolated from an oilfieldwater injection sample, and emended description of the family Halomonadaceae Franzmann et al. 1989 emend Dobson and
Franzmann 1996 emend. Ntougias et al. 2007. Int J Syst Evol Microbiol 57, 2307-2313.

Cabrera, A., Aguilera, M., Fuentes, S., Incerti, C., Russell, N. J., Ramos-Cormenzana, A. \& Monteoliva-Sanchez, M. (2007). Halomonas indalinina sp. nov., a moderately halophilic bacterium isolated from a solar saltern in Cabo de Gata, Almeria, southern Spain. Int J Syst Evol Microbiol 57, 376-380.

Dobson, S. J. \& Franzmann, P. D. (1996). Unification of the genera Deleya (Baumann et al. 1983), Halomonas (Vreeland et al. 1980), and Halovibrio (Fendrich 1988) and the species Paracoccus halodenitrificans (Robinson and Gibbons 1952) into a single genus, Halomonas, and placement of the genus Zymobacter in the family Halomonadaceae. Int J Syst Bacteriol 46, 550-558.

Dobson, S. J., McMeekin, T. A. \& Franzmann, P. D. (1993). Phylogenetic relationships between some members of the genera Deleya, Halomonas, and Halovibrio. Int J Syst Bacteriol 43, 665673.

Dussault, H. P. (1955). An improved technique for staining red halophilic bacteria. J Bacteriol 70, 484-485.

Fairley, D. J., Boyd, D. R., Sharma, N. D., Allen, C. C. R., Morgan, P. \& Larkin, M. J. (2002). Aerobic metabolism of 4-hydroxybenzoic acid in Archaea via an unusual pathway involving an intramolecular migration (NIH shift). Appl Environ Microbiol 68, 6246-6255.

Franzmann, P. D., Wehmeyer, U. \& Stackebrandt, E. (1988). Halomonadaceae fam. nov., a new family of the class Proteobacteria to accommodate the genera Halomonas and Deleya. Syst Appl Microbiol 11, 16-19.

Garriga, M., Ehrmann, M. A., Arnau, J., Hugas, M. \& Vogel, R. F. (1998). Carnimonas nigrificans gen. nov., sp. nov., a bacterial causative agent for black spot formation on cured meat products. Int J Syst Bacteriol 48, 677-686.

Mata, J. A., Martínez-Cánovas, J., Quesada, E. \& Béjar, V. (2002). A detailed phenotypic characterisation of the type strains of Halomonas species. Syst Appl Microbiol 25, 360-375.

Mesbah, M., Premachandran, U. \& Whitman, W. B. (1989). Precise measurement of the $\mathrm{G}+\mathrm{C}$ content of deoxyribonucleic acid by highperformance liquid chromatography. Int J Syst Bacteriol 39, 159167.

Sánchez-Porro, C., de la Haba, R. R., Soto-Ramírez, N., Márquez, M. C., Montalvo-Rodríguez, R. \& Ventosa, A. (2009). Description of Kushneria aurantia gen. nov., sp. nov., a novel member of the family Halomonadaceae, and a proposal for reclassification of Halomonas marisflavi as Kushneria marisflavi comb. nov., of Halomonas indalinina as Kushneria indalinina comb. nov. and of Halomonas avicenniae as Kushneria avicenniae comb. nov. Int J Syst Evol Microbiol 59, 397405.

Soto-Ramirez, N., Sánchez-Porro, C., Rosas, S., Gonzalez, W., Quinones, M., Ventosa, A. \& Montalvo-Rodriguez, R. (2007). Halomonas avicenniae sp. nov., isolated from the salty leaves of the black mangrove Avicennia germinans in Puerto Rico. Int J Syst Evol Microbiol 57, 900-905.

Tamura, K., Dudley, J., Nei, M. \& Kumar, S. (2007). MEGA4: Molecular evolutionary genetics analysis (MEGA) software version 4.0. Mol Biol Evol 24, 1596-1599.

Thompson, J. D., Higgins, D. G. \& Gibson, T. J. (1994). CLUSTAL W: improving the sensitivity of progressive multiple sequence alignment through sequence weighting, position-specific gap penalties and weight matrix choice. Nucleic Acids Res 22, 4673-4680.

Ventosa, A., Quesada, E., Rodriguez-Valera, F., Ruiz-Berraquero, F. \& Ramos-Cormenzana, A. (1982). Numerical taxonomy of moderately halophilic Gram-negative rods. J Gen Microbiol 128, 19591968. 
Ventosa, A., Nieto, J. J. \& Oren, A. (1998). Biology of moderately halophilic aerobic bacteria. Microbiol Mol Biol Rev 62, 504-544.

Wilson, K. H., Blitchington, R. B. \& Greene, R. C. (1990). Amplification of bacterial $16 \mathrm{~S}$ ribosomal DNA with polymerase chain reaction. J Clin Microbiol 28, 1942-1946.

Xie, C. H. \& Yokota, A. (2003). Phylogenetic analyses of Lampropedia hyalina based on the 16S rRNA gene sequence. J Gen Appl Microbiol 49, 345-349.
Yoon, J. H., Choi, S. H., Lee, K. C., Kho, Y. H., Kang, K. H. \& Park, Y. H. (2001). Halomonas marisflavae sp. nov., a halophilic bacterium isolated from the Yellow Sea in Korea. Int J Syst Evol Microbiol 51, 1171-1177.

Yoon, J. H., Lee, K. C., Kho, Y. H., Kang, K. H., Kim, C. J. \& Park, Y. H. (2002). Halomonas alimentaria sp. nov., isolated from jeotgal, a traditional Korean fermented seafood. Int J Syst Evol Microbiol 52, 123-130. 